

\section{LEGAL NOTICE}

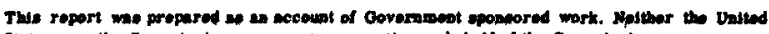

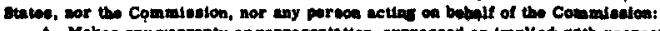

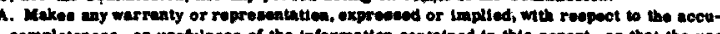

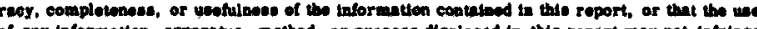
of my talor action, arenratus, mothod, or procoso privetely owaed rtebte; or

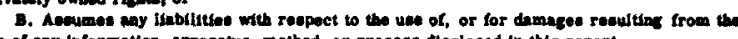
un of any taformation, apperatue, method, or procese diecloned in this report.

Ao uned in the above, "porcon acting on bebalf of the Comminolon" includes any omployee or contractor of the Commination, or exployee of such confritetor, to the extent that

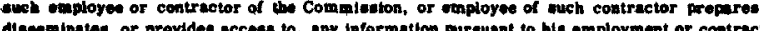

Printed in the United States of America Available from

Clearinghouse for Federal Scientific and Technical Information National Bureau of Standards, U. S. Department of Commerce Springfield, Virginia 22151

Price: Printed Copy $\$ 3.00$; Microfiche $\$ 0.65$ 


\section{DISCLAIMER}

This report was prepared as an account of work sponsored by an agency of the United States Government. Neither the United States Government nor any agency Thereof, nor any of their employees, makes any warranty, express or implied, or assumes any legal liability or responsibility for the accuracy, completeness, or usefulness of any information, apparatus, product, or process disclosed, or represents that its use would not infringe privately owned rights. Reference herein to any specific commercial product, process, or service by trade name, trademark, manufacturer, or otherwise does not necessarily constitute or imply its endorsement, recommendation, or favoring by the United States Government or any agency thereof. The views and opinions of authors expressed herein do not necessarily state or reflect those of the United States Government or any agency thereof. 


\section{DISCLAIMER}

Portions of this document may be illegible in electronic image products. Images are produced from the best available original document. 


\title{
AMERICIUM, CURIUM, AND PLUTONIUM YIELDS IN SRP HIGH FLUX IRRADIATIONS
}

\author{
by \\ C. J. Banick \\ Approved by \\ E. L. Albenesius, Research Manager \\ Analytical Chemistry Division \\ July 1968
}

E. I. DU PONT DE NEMOURS \& COMPANY SAVANNAH RIVER LABORATORY

AIKEN, S. C. 29801

CONTRACT AT(07.2)-1 WITH THE

UNITED STATES ATOMIC ENERGY COMMISSION 


\begin{abstract}
Analyses of sections of four ${ }^{242} \mathrm{PuO}_{2}$ targets irradiated at high flux in SRP reactors indicate that the ${ }^{244} \mathrm{Cm}$ and ${ }^{245} \mathrm{Cm}$ yields are near equilibrium between exposures of $5 \times 10^{22} \mathrm{n} / \mathrm{cm}^{2}$ and $9 \times 10^{22} \mathrm{n} / \mathrm{cm}^{2}$. High fission losses reduce yields of higher mass isotopes at these exposures. The yields of ${ }^{246} \mathrm{Cm},{ }^{247} \mathrm{Cm}$, and ${ }^{248} \mathrm{Cm}$ are still increasing at $9 \times 10^{22} \mathrm{n} / \mathrm{cm}^{2}$. Fission products correspond to the consumption of $\sim 29 \%$ of the initial plutonium after an exposure of $9 \times 10^{22} \mathrm{n} / \mathrm{cm}^{2}$.
\end{abstract}




\section{AMERICIUM, CURIUM, AND PLUTONIUM YIELDS IN SRP HIGH FLUX IRRADIATIONS}

A total of $520 \mathrm{~g}$ of ${ }^{242} \mathrm{Pu}$, including eight ${ }^{242} \mathrm{PuO}_{2} \mathrm{~s}$ lugs, were irradiated at high flux $\left[\sim 3 \times 10^{15} \mathrm{n} /\left(\mathrm{cm}^{2}\right)(\mathrm{sec})\right]$ in $\mathrm{SRP}$ reactors to produce higher mass isotopes to serve as target material for the High Flux Isotopes Reactor (HFIR) at Oak Ridge. ${ }^{1}$ Production rates of the transplutonium isotopes were needed to develop effective cross sections for extended high flux irradiation; for this purpose, four of the ${ }^{242} \mathrm{PuO}_{2}$ slugs were discharged and analyzed after exposures ranging from $3.7 \times 10^{22}$ to $9.3 \times 10^{22} \mathrm{n} / \mathrm{cm}^{2}$. Nuclides through ${ }^{248} \mathrm{Cm}$ have been determined from the first of these slugs (P-3). ${ }^{2}$ Similar determinations on slugs P-4, P-5, and P-6 are summarized in this report. Yields of transcurium nuclides in all four slugs have been reported by Holcomb. ${ }^{3}$

A11 four target slugs were of identical size, shape, and ${ }^{242} \mathrm{Pu}$ content. Duplicate wafers representing about one tenth of the total core weight were cut from the center of each slug. The wafers were then digested in $\mathrm{NaOH}$. The reaction mass was acidified with $\mathrm{HNO}_{3}-\mathrm{HF}$, and then diluted, sampled, and analyzed as described previously. ${ }^{2}$ Exposures were computed from power estimates and also by calculations in which a 17.5 -barn burnup cross section for ${ }^{242} \mathrm{Pu}$ was used.

Americium, curium, and plutonium determinations in al1 four slugs are summarized in the table. These results are fitted to yield-exposure curves in the figure with a computer program for multiple neutron captures. ${ }^{4}$ In this method, key cross sections are varied, and an iterative approach is used until the observed actinide yields are obtained. The resulting set of cross sections can be used for calculating yields from other irradiations of this type. These calculations have been reported in detail. ${ }^{4}$

Mass spectrometric analyses of the curium fraction indicate that ${ }^{247} \mathrm{Cm}$ and ${ }^{248} \mathrm{Cm}$ have equal yields at about $6 \times 10^{22} \mathrm{n} / \mathrm{cm}^{2}$. Yields of ${ }^{246} \mathrm{Cm},{ }^{247} \mathrm{Cm}$, and ${ }^{248} \mathrm{Cm}$ continue to increase even after exposures 
of $9 \times 10^{22}$. ${ }^{245} \mathrm{Cm}$ with its rather high fission cross section is roughly in equilibrium with the ${ }^{244} \mathrm{Cm}$ throughout this range. Fission products, which account for less than $9 \%$ of initial plutonium after an exposure of $3.7 \times 10^{22}$, correspond to as much as $29 \%$ of initial plutonium after an exposure of $9 \times 10^{22} \mathrm{n} / \mathrm{cm}^{2}$.

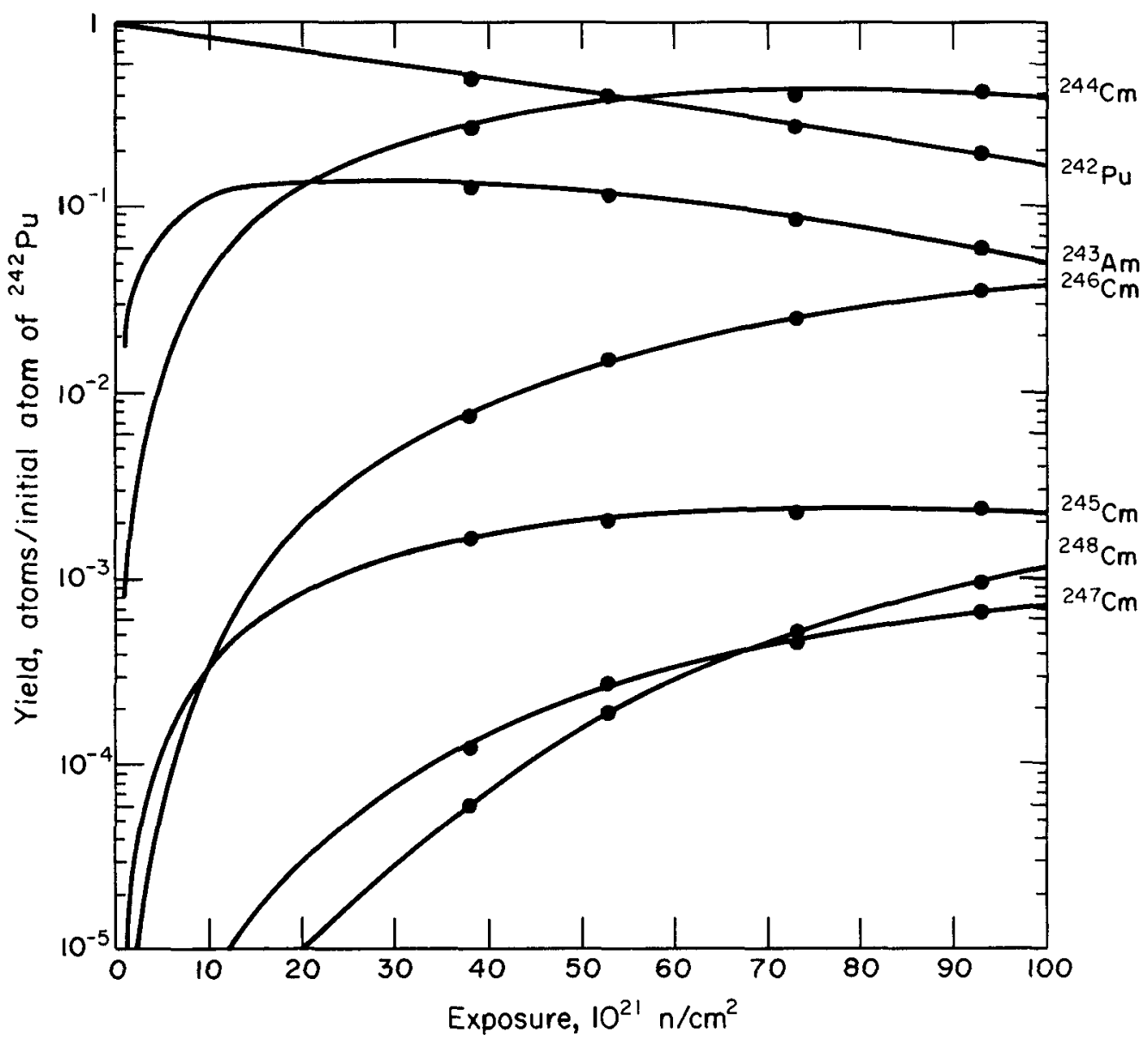

FIG. 1 YIELDS OF ACTINIDES CALCULATED WITH DEDUCED CROSS SECTIONS 
Analyses of $242 \mathrm{Pu}$ Irradiated at High Flux

\begin{tabular}{|c|c|c|c|c|}
\hline Target & $P-3$ & $\mathrm{P}-4$ & $P-5$ & $P-6$ \\
\hline \multicolumn{5}{|c|}{ Exposure, $10^{22} \mathrm{n} / \mathrm{cm}^{2}$} \\
\hline Estimated ${ }^{a}$ & 3.7 & 5.3 & 7 & 9 \\
\hline Calculated ${ }^{b}$ & 3.8 & 5.2 & 7.3 & 9.3 \\
\hline \multicolumn{5}{|c|}{$\begin{array}{l}\text { Actinide, } g_{2} \text { per } \\
\text { initial } g\end{array}$} \\
\hline $242 \mathrm{Pu}$ & 0.511 & 0.402 & 0.276 & 0.194 \\
\hline $243 \mathrm{Am}$ & $0.128^{c}$ & 0.122 & 0.091 & 0.065 \\
\hline $2{ }^{44} \mathrm{Cm}$ & 0.276 & 0.374 & 0.417 & 0.430 \\
\hline
\end{tabular}

Fission Products, $g$ per initial g plutonium irradiated
0.088
0.147
0.214
0.29

Total Products, $g$ per $g$ plutonium irradiated
0.991
1.05
1.021 .03

Isotopic Composition, wt $\%$

$\begin{array}{lccccc}23{ }^{8} \mathrm{Pu} & \frac{\text { Initial }}{0.44} & <5 \times 10^{-3} & <\times 10^{-3} & - & <3 \times 10^{-5} \\ 2{ }^{39} \mathrm{Pu} & 0.35 & 0.017 & 0.003 & 0.008 & <3 \times 10^{-5} \\ 2{ }^{20} \mathrm{Pu} & 1.71 & 0.112 & 0.11 & 0.401 & 0.460 \\ 2{ }^{41} \mathrm{Pu} & 0.62 & 0.023 & 0.040 & 0.134 & 0.137 \\ 2{ }^{42} \mathrm{Pu} & 96.89 & 99.53 & 99.35 & 98.71 & 98.29 \\ 2{ }^{4}{ }^{4} \mathrm{Pu} & 0.05 & 0.321 & 0.50 & 0.733 & 1.12 \\ 2{ }^{4{ }^{4} \mathrm{Cm}} & & 96.63 & 95.33 & 93.58 & 91.47 \\ 2{ }^{45} \mathrm{Cm} & & 0.580 & 0.535 & 0.504 & 0.487 \\ 2{ }^{46} \mathrm{Cm} & & 2.71 & 3.97 & 5.70 & 7.69 \\ 2{ }^{47} \mathrm{Cm} & & 0.044 & 0.072 & 0.104 & 0.141 \\ 2{ }^{48} \mathrm{Cm} & & 0.022 & 0.06 & 0.116 & 0.208\end{array}$

a From power data

busing 17.5-barn burnup cross section for ${ }^{242} \mathrm{Pu}$

Corrected from value in DP-1046

$\mathrm{d}_{\text {Assumes that the mean effective mass of fissioning nuclei }}$ is $242(\mathrm{P}-3), 243(\mathrm{P}-4), 245(\mathrm{P}-5)$, and $245(\mathrm{P}-6)$ with ${ }^{3}{ }^{7} \mathrm{Cs}$ fission yields of $6.0 \%$ for mass 242 and 243 and $7.9 \%$ for mass 245 . ${ }^{137} \mathrm{Cs}$ was determined by the tetraphenylboron method. 
$-6-$ 
0

0 


\section{REFERENCES}

1. J. L. Cranda11. The Savannah River High Flux Demonstration. USAEC Report DP-999, E. I. du Pont de Nemours and Co., Savannah River Laboratory, Aiken, S. C. (1965).

2. E. K. Dukes, R. L. Folger, C. J. Banick, G. A. Carothers, M. Y. Donnan. Yiezd of Curium-244 in the SRP High Flux Reactor. USAEC Report DP-1046, E. I. du Pont de Nemours and Co., Savannah River Laboratory, Aiken, S. C. (1966).

3. H. P. Holcomb. Yields of Transourium Nuclides in the SRP High Flux Reactor. USAEC Report DP-1137, E. I. du Pont de Nemours and Co., Savannah River Laboratory, Aiken, S. C. (1967).

4. J. A. Smith, C. J. Banick, R. L. Folger, H. P. Holcomb, and I. B. Richter. Reactor Cross Sections for 242 Pu-252Cf. Paper presented at the Conference on Neutron Cross Sections and Technology, Washington, March 1968. To be published in the Proceedings of the Meeting. 